\title{
Altered E-Cadherin Expression and p120 Catenin Localization in Esophageal Squamous Cell Carcinoma (ESCC)
}

\section{Short title: Altered E-cadherin and p120ctn in ESCC}

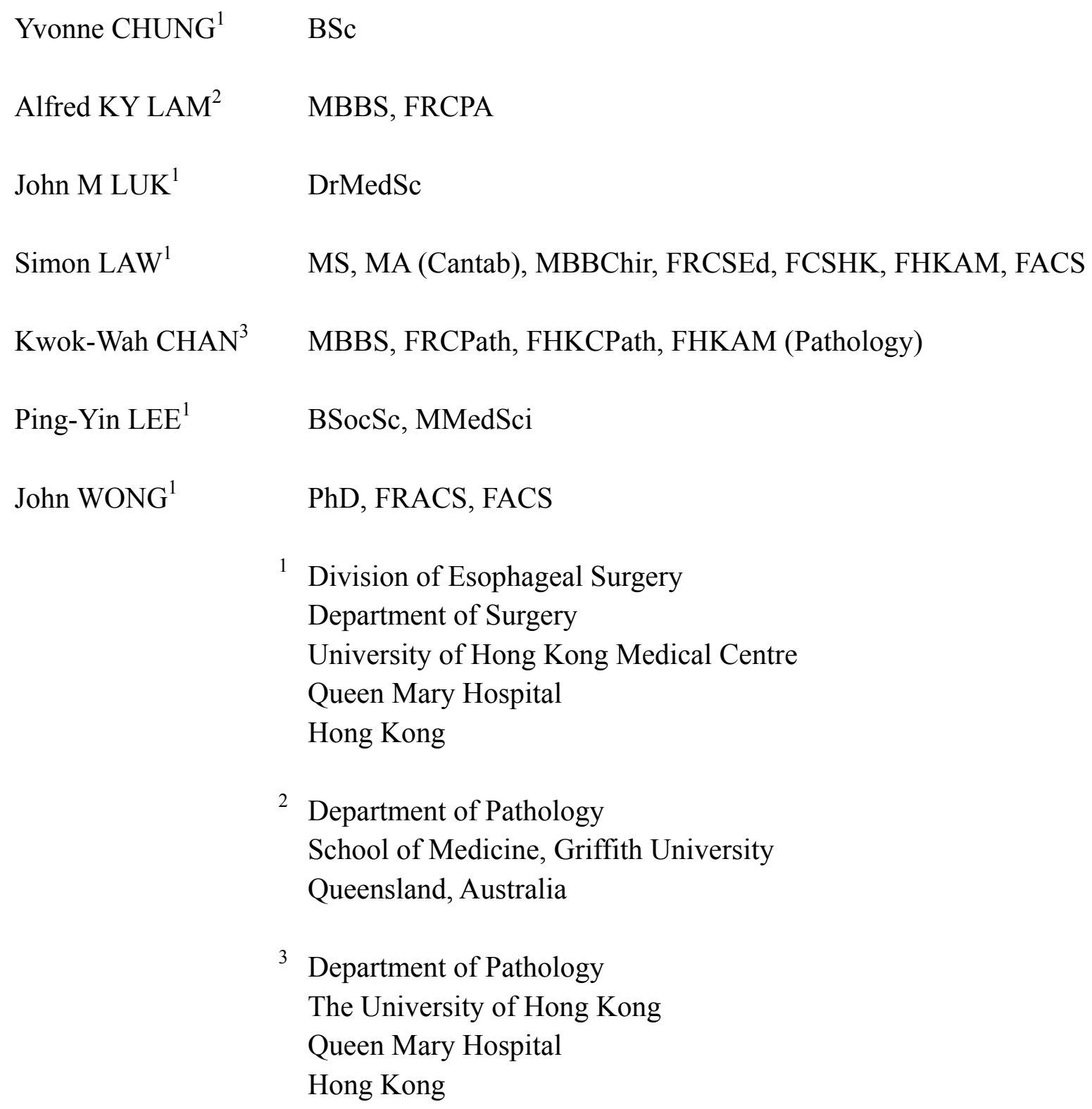


Corresponding author for proof and reprints:

Professor Simon Law

Department of Surgery

Li Ka Shing Faculty of Medicine

University of Hong Kong Medical Centre

Queen Mary Hospital

102 Pokfulam Road

Hong Kong

Tel: (852) 28554774

Fax: (852) 28194221

Email: slaw@hku.hk 


\section{ABSTRACT}

Background: E-cadherin is a well known tumor suppressor and its dysregulated expression correlates with tumor differentiation, metastasis and survival in esophageal squamous cell carcinoma (ESCC). p120 catenin is an Armadillo protein normally bound to E-cadherin in the cadherin-catenin complex at the adherens junction. Dysregulated expression and mislocalization of p120ctn affect its protective function of the complex. The objective of the present study was to evaluate the clinical significance of E-cadherin and p120ctn expression in ESCC.

Methods: Immunohistochemistry was performed to investigate the expression of E-cadherin and p120ctn proteins in 71 ESCC patients. The relationships between protein expression and clinicopathological characteristics were analyzed.

Results: Reduced E-cadherin and p120ctn expressions were observed in $42.3 \%$ and $8.5 \%$ of ESCC cases respectively. Reduction of membranous p120ctn was observed in $33.8 \%$ of cases. Membranous E-cadherin was preserved when p120ctn co-localized on the membrane of tumor cells $(72.3 \%, P=0.001)$. High level E-cadherin expression and membranous p120ctn preservation positively correlated with tumor differentiation ( $P=0.001$ and $P=0.008$ respectively). p120ctn expression was also significantly related to 
lymph node metastasis $(P=0.003)$. Heterogeneous expression of both E-cadherin and p120ctn was observed in dysplasia.

Conclusions: Altered E-cadherin expression and p120ctn localization were related to tumor differentiation, indicating their important roles in the pathogenesis of ESCC.

Key Words: E-cadherin, esophageal squamous cell carcinoma (ESCC), immunohistochemistry, p120 catenin, tumor differentiation. 


\section{INTRODUCTION}

Esophageal cancer is the sixth most frequent cause of cancer death in the world. Among all histological subtypes, squamous cell carcinoma (ESCC) is the commonest one in Asia and locally in Hong Kong. ${ }^{1}$ Unfortunately, the overall prognosis remains relatively poor, mostly because of late diagnosis, the propensity of early spread of disease, and its occurrence in a group of elderly patients with co-morbid illnesses. The identification of a sensitive and representative disease marker is important for prognostication and to guide appropriate treatment. $^{2}$

E-cadherin is a $120 \mathrm{kDa}$ transmembrane glycoprotein belonging to the superfamily of $\mathrm{Ca}^{2+}$-dependent cell adhesion molecules. It is mainly found in epithelial cells and plays a key role in cell-cell interaction. Normally E-cadherin functions as a mediator for tight intercellular adhesion, cell polarity and tissue architecture maintenance. ${ }^{3}$ It is also a well known tumor suppressor and downregulation of protein expression has been reported in many cancers including gastric, colorectal, breast and bladder cancers. ${ }^{4-12}$ Genetic mutations, loss of heterozygosity and hypermethylation of its promoter are some factors causing dysregulated E-cadherin expression in carcinomas. ${ }^{13,14}$ In ESCC, reduced E-cadherin expression has been reported to correlate with tumor differentiation, metastasis 
and prognosis. $^{15-21}$

p120 catenin (p120ctn) was first identified to be an efficient tyrosine kinase substrate implicated in cell transformation by Src. It belongs to the Armadillo protein superfamily due to the possession of 10 Arm repeats. The human p120ctn gene (CTNND1) consists of 21 exons and makes up to 32 isoforms resulting from alternative splicing. Isoforms 1 to 4 differs from each other by four different start sites and additional splicing products are formed by combinations of alternatively existing exons A (exon 18), B (exon 20) and C (exon 11). ${ }^{22}$ p120ctn is ubiquitously expressed at high levels bound to E-cadherin on the plasma membrane directly at the juxtamembrane domain (JMD). It regulates cadherin turnover at the cell surface and its dissociation promotes cadherin internalization. It also stabilizes E-cadherin and rescues its function post-translationally. ${ }^{23}$ Besides cellular adhesive function, p120ctn is also involved in the regulation of cell motility through actin cytoskeleton remodeling via Rho, Rac and Cdc42 GTPases. ${ }^{24-27}$ Recent studies indicated that p120ctn downregulation was correlated with poorly differentiated tumor and metastatic phenotype in certain cancers. ${ }^{12,28,29}$

The purpose of the present study was to evaluate the clinical significance of E-cadherin and p120ctn expression and their inter-relationship in prognostication of ESCC. 


\section{MATERIALS AND METHODS}

\section{Patients and Specimens}

Seventy-one patients with esophageal squamous cell cancers (ESCC) who underwent esophagectomy between 1997 and 2005 at the Department of Surgery, University of Hong Kong Medical Centre, Queen Mary Hospital, Hong Kong were recruited in this study. There were 50 men and 21 women; the mean age of the subjects was $65.0 \pm 11.4$ years (range 40 - 87 years). None of these patients had received neo-adjuvant chemotherapy or radiotherapy. Patient demographics and data concerning their operation, histopathology, and long-term follow-up data were captured in a prospectively collected database. Specimens of the primary tumor and non-tumor tissues from the proximal resection margins were obtained for storage and analyses.

Macroscopically, the site and size of the primary tumors were recorded. Standard blocks were taken and fixed in 10\% formalin followed by embedding in paraffin wax. Histological sections were cut at $4 \mu \mathrm{m}$ and stained with hematoxylin and eosin for light microscopy. Stained sections were reviewed and classified into different grades by the World Health Organization (WHO) criteria. The cancers were staged according to TNM classification. ${ }^{30}$ Representative blocks from the tumor and non-tumor tissue from each specimen were 
chosen for immunohistochemical study.

\section{Immunohistochemistry}

Both tumor and non-tumor tissue blocks were cut into $4 \mu \mathrm{m}$-thick sections and mounted on glass slides. Immunohistological staining was performed using the EnVision method as described previously. ${ }^{31}$ Briefly, the sections were deparaffinized and rehydrated. Antigens were retrieved in preheated $0.2 \mathrm{M}$ citrate buffer $\left(\mathrm{pH}\right.$ 6) with microwave at $95^{\circ} \mathrm{C}$ for 12 minutes. Subsequently, endogenous peroxidase activity was blocked by $3 \%$ hydrogen peroxide at room temperature for 20 minutes. After washing with 1x Tris buffered saline (TBS), nonspecific antigens were blocked with $2 \%$ bovine serum albumin (BSA, Sigma, St Louis, MO, USA) in TBS for 1 hour. The sections were then incubated with primary antibodies overnight at $4^{\circ} \mathrm{C}$. Primary antibodies included mouse monoclonal anti-E-cadherin (HECD-1) antibody (Cat No.13-1700, Zymed Laboratories, Carlsband, CA, USA) and mouse monoclonal anti-p120 ${ }^{\mathrm{ctn}}$ (CT) antibody (Cat No.33-9600, Zymed Laboratories) in the same dilution of 1:200. Following washing with TBS, the sections were incubated with anti-mouse horseradish peroxidase-labeled polymer-conjugated secondary antibody (EnVision+ System-HRP, Cat No.K4007, DakoCytomation, Glostrup, Denmark) at room temperature for 30 minutes. Excess antibodies were removed by TBS 
and signal was visualized by Liquid DAB Substrate Kit (Cat No.00-2014, Zymed Laboratories). Tissues were counterstained with hematoxylin and dehydrated prior to mounting. Negative control was designed by using mouse IgG (Cat No.02-6502, Zymed Laboratories) as primary antibody. Known immunoreactive sections were used as positive controls.

\section{Immunohistochemistry Evaluation}

Tissue sections were assessed by light microscopy by a pathologist (AKYL). The grading of immunoreactivity was conducted according to staining intensity of tumor section compared with that of the corresponding non-tumor tissue. Staining intensity was classified into two categories: (a) complete loss / reduced expression and (b) preserved staining. Specifically for p120ctn staining activity, localization of the protein antigen was also documented and was classified as (a) absent / reduced membranous staining or (b) preserved membranous staining.

\section{Statistical Analysis}

$\chi^{2}$ test or Fisher's exact probability test was used to assess the association between immunohistochemical reactivity and clinicopathological characteristics. The Kaplan-Meier method was employed for survival analysis and differences in survival were estimated 
using the log rank test. A $P$ value less than 0.05 was considered statistically significant. All the statistical analyses were performed using SPSS 13.0 for Windows (Chicago, IL, USA).

\section{RESULTS}

\section{Expression of E-cadherin and p120ctn in esophageal squamous cell carcinomas}

E-cadherin was mainly observed on the cell membrane of both non-tumor and tumor tissues (Fig. $1 A \& C$ ). Complete loss or reduced E-cadherin expression was detected in $42.3 \%(30 / 71)$ of ESCC patients. On the other hand, p120ctn expression was well preserved in the majority of ESCC patients $(91.5 \%, 65 / 71)$. Unlike E-cadherin, it was found on both cell membrane and cytoplasm of non-tumor cells (Fig. 1 B). Absent or reduced membranous p120ctn was observed in 33.8\% (24/71) of ESCC patients (Fig. 1 D).

\section{Relationship between E-cadherin and p120ctn expression and localization}

p120ctn membranous localization was related to membranous expression of E-cadherin. When p120ctn was found on cell membrane, preserved membranous expression of E-cadherin was observed in 34 of 47 (72.3\%) of patients. But when p120ctn was lost or accumulated in cytoplasm, membranous expression of E-cadherin was only found in 7 or $24(29.2 \%)$ patients $(\mathrm{P}=0.001)$ (Table 1). This suggests that $\mathrm{p} 120 \mathrm{ctn}$ membrane localization 
had direct effect on membranous expression of E-cadherin.

\section{Relationship between expression of E-cadherin and tumor differentiation in ESCC}

Preservation of E-cadherin was noted in all well differentiated ESCC cases $(100 \%$, 12/12). In contrast, E-cadherin was lost or detected at low levels in most of the poorly differentiated ESCC patients $(73.3 \%, 11 / 15)$. A trend of increasing number of E-cadherin preserved cases from poorly to well differentiated cancer patients was observed. Heterogeneous expression pattern was also detected in the regions of squamous dysplasia (Fig. 1 E). A significant relationship was found between E-cadherin expression and ESCC tumor differentiation $(P=0.001)$ (Table 2).

\section{Relationship between localization of p120ctn and tumor differentiation in ESCC}

Two of 12 well differentiated ESCC patients (8.3\%) were found to have membranous loss of p120ctn from membrane to cytoplasm. The p120ctn mislocalization was detected in the poorly and moderately differentiated cases in $91.7 \%$, (22/24). Among cases with preserved membranous p120ctn protein, $89.4 \%$ (42/47) had moderately or well differentiated tumors. Both gradual decrease in expression and increase in mislocalization of p120ctn protein were seen in squamous dysplasia (Fig. $1 F$ ). Thus the localization of p120ctn significantly correlated with tumor differentiation in $\operatorname{ESCC}(P=0.008)$ (Table 3$)$. 


\section{Relationship between p120ctn expression and lymph node metastasis}

Among all the patients with preserved p120ctn expression, 66.2\% (43/65) showed lymph

node metastases (N1). In the cases with either complete loss or reduction in the expression of $\mathrm{p} 120 \mathrm{ctn}$, none $(0 \%, 0 / 6)$ had lymph node metastasis $(\mathrm{p}=0.003)$.

Relationship between E-cadherin and p120ctn expression and localization and clinicopathological features

No statistical significant relationship was found when E-cadherin and p120ctn expression and localization were correlated with other clinicopathological features including age, gender, smoking status, level of tumor, R category, pathological T-stage and M-stage, as well as pathological stage (Tables $2 \& 3$ ).

Relationship between E-cadherin and p120ctn expression and localization and survival

There were no significant differences in survival when patients were grouped and compared according to E-cadherin expression, p120ctn expression and p120ctn localization ( $P=0.927 ; P=0.700$ and $P=0.183$ respectively) (Fig. $2 A, B \& C$ ). All three factors had no significant predictive value in ESCC patient survival. 


\section{DISSCUSSION}

In the present study, we demonstrated that membranous expression of E-cadherin and p120ctn was found in non-tumor tissues of the esophagus, but complete loss or reduction of E-cadherin expression was shown in $42.3 \%$ of ESCC tumors. This is similar to other cancers previously reported. ${ }^{8,11,21,32}$ The reduced E-cadherin protein expression was associated with tumor differentiation $(P=0.001)$ but not the other clinicopathological parameters that were analyzed. In previous studies, downregulated E-cadherin expression was also observed according to the decreasing degree of tumor differentiation in ESCC. ${ }^{15,16}$ In esophageal adenocarcinoma, heterogeneous staining pattern with gradually diminishing expression of E-cadherin was seen from regions of metaplasia to dysplasia and to carcinoma, which indicated that the reduction of E-cadherin expression might also play a role in tumor progression in ESCC. ${ }^{33}$ In the present study on ESCC, heterogeneous expression of E-cadherin was also noted in dysplastic mucosa adjacent to the carcinoma.

E-cadherin expression is associated with higher metastatic rate in colorectal cancer, ESCC and head and neck squamous cell carcinoma. ${ }^{8,19,34,35}$ However, we could not demonstrate any significant relationship between E-cadherin expression level and lymph node metastasis $(P=0.332)$. It is worth noting that expression of $\mathrm{N}$-cadherin promotes cell 
motility, invasion and metastasis even in the presence of high level of E-cadherin in breast cancer. ${ }^{10,36}$ Thus, other cadherins such as $\mathrm{N}$-cadherin may participate in intercellular adhesion compensating the loss of E-cadherin function. ${ }^{11}$ Another reason for the preserved level of E-cadherin in ESCC with lymph node metastasis might be the detected proteins were the mutant with a larger molecular weight but no cell-cell adhesion ability. ${ }^{37}$

p120ctn normally binds to the juxtamembrane domain (JMD) of E-cadherins exerting a stabilizing effect in normal tissue. ${ }^{23}$ In earlier studies, p120ctn protein was detected in cell-cell boundaries in benign tumors and normal tissues but in cytoplasm in carcinomas. ${ }^{9,28,38}$ In our IHC results, it did not show an overall decreased expression of p120ctn in most of the ESCC cases, but absent or decreased membranous expression and cytoplasmic accumulation were observed. Since p120ctn is a metabolically stable protein, its expression and half-life are not affected by the absence of cadherins and that might be the reason why our findings did not show a significant relationship between E-cadherin expression and $\mathrm{p} 120 \mathrm{ctn}$ expression $(P=0.233)$ (Data not shown). ${ }^{39-41}$

In this study, mislocalization of p120ctn from cell membrane to cytoplasm was significantly associated with the loss or reduction in membranous E-cadherin in ESCC ( $P=0.001)$. Recently, there were two proposed mechanisms to explain such a relationship. 
First, mislocalization of p120ctn in cytoplasm leads to its incapability of interacting with E-cadherin, and consequently loses its protective effect, and eventually internalization and degradation of membranous E-cadherin. ${ }^{41}$ Membranous derangement of p120ctn might be due to the p120ctn-microtubule network association directly or indirectly through the interaction with kinesin, ${ }^{42}$ or an increased $\delta$-catenin pool which competes with p120ctn for the JMD on cadherins. ${ }^{43}$ Second is the insufficient capture of cytoplasmic p120ctn to cell membrane by downregulated E-cadherin leading to accumulation of excess p120ctn in the cytoplasm. ${ }^{9,35}$

In this study, p120ctn overall expression was preserved in all pathological N1 ESCC cases. This is in contrast to the findings of Bremnes et al. for lung cancer. ${ }^{29}$ It may be due to the fact that our samples are of a different cancer type by which it is not comparable as p120ctn expression is tissue and cell type specific. ${ }^{44}$ In addition, it has been suggested that different isoforms of p120ctn might display different functions. Aho and colleagues showed that certain isoforms of p120ctn did not induce branching phenotype while others did. Isoforms $4 \mathrm{~A}$ and $1 \mathrm{AB}$ might have tumor-suppressor roles in skin cancer. ${ }^{45}$ Herein, we used a primary antibody which recognized all 4 isoforms of p120ctn and therefore all detected proteins were indistinguishable. The differential expression profiles of different isoforms 
might account for the unexpected different results. It might also explain why there was no apparent significant relationship between p120ctn localization and pathological N-stage even though we understood that the p120ctn-uncoupled E-cadherin was vulnerable to endocytosis and hence losing its cell-cell adhesive ability.

p120ctn has been reported as an independent prognostic marker in gastroesophageal adenocarcinoma. ${ }^{28}$ In the present study, p120ctn localization in ESCC showed a significant relationship with tumor differentiation $(P=0.008)$. Membranous p120ctn protein was mostly preserved in well differentiated tumors but lost or reduced in poorly differentiated ones. It is also present occasionally in dysplastic mucosa, indicating that p120ctn localization might take part in tumor progression. However, no significant relationship between p120ctn expression and survival rate was noted in ESCC.

In conclusion, E-cadherin expression and p120ctn localization were associated with ESCC tumor differentiation, and in addition, p120ctn expression was related to lymph node metastasis. To our knowledge, this was the first time that a significant relationship between E-cadherin expression and p120ctn localization was demonstrated in ESCC. In spite of the lack of prognostic value of E-cadherin and p120ctn in ESCC, assessment of both E-cadherin expression and co-localization of E-cadherin and p120ctn could hint to tumor 
progression. The prevalence of changes in these markers may be useful for planning treatment strategy for ESCC in future clinical management and further studies on their roles in tumorigenesis are necessary. 


\section{References}

1. Lam KY, Ma L. Pathology of esophageal cancers: local experience and current insights. Chin Med J (Engl ) 1997; 110:459-464.

2. Lam AK. Molecular biology of esophageal squamous cell carcinoma. Crit Rev Oncol Hematol 2000; 33:71-90.

3. Takeichi M. Cadherin cell adhesion receptors as a morphogenetic regulator. Science $1991 ; 251: 1451-1455$.

4. Jawhari AU, Noda M, Farthing MJ, Pignatelli M. Abnormal expression and function of the E-cadherin-catenin complex in gastric carcinoma cell lines. Br J Cancer 1999; 80:322-330.

5. Chan AO, Wong BC, Lan HY et al. Deregulation of E-cadherin-catenin complex in precancerous lesions of gastric adenocarcinoma. J Gastroenterol Hepatol 2003; 18:534-539. 
6. Karatzas G, Karayiannakis AJ, Syrigos KN et al. Expression patterns of the E-cadherin-catenin cell-cell adhesion complex in gastric cancer.

Hepatogastroenterology 2000; 47:1465-1469.

7. Valizadeh A, Karayiannakis AJ, el-Hariry I, Kmiot W, Pignatelli M. Expression of E-cadherin-associated molecules (alpha-, beta-, and gamma-catenins and p120) in colorectal polyps. Am J Pathol 1997; 150:1977-1984.

8. Ghadimi BM, Behrens J, Hoffmann I, Haensch W, Birchmeier W, Schlag PM. Immunohistological analysis of E-cadherin, alpha-, beta- and gamma-catenin expression in colorectal cancer: implications for cell adhesion and signaling. Eur J Cancer 1999; 35:60-65.

9. Sarrio D, Perez-Mies B, Hardisson D et al. Cytoplasmic localization of p120ctn and E-cadherin loss characterize lobular breast carcinoma from preinvasive to metastatic lesions. Oncogene 2004; 23:3272-3283.

10. Nieman MT, Prudoff RS, Johnson KR, Wheelock MJ. N-cadherin promotes motility 
in human breast cancer cells regardless of their E-cadherin expression. J Cell Biol 1999; 147:631-644.

11. Mialhe A, Levacher G, Champelovier P, Martel V, Serres M, Knudsen K, Seigneurin D. Expression of E-, P-, n-cadherins and catenins in human bladder carcinoma cell lines. J Urol 2000; 164:826-835.

12. Nakopoulou L, Zervas A, Gakiopoulou-Givalou H, Constantinides C, Doumanis G, Davaris P, Dimopoulos C. Prognostic value of E-cadherin, beta-catenin, P120ctn in patients with transitional cell bladder cancer. Anticancer Res 2000; 20:4571-4578.

13. Berx G, Becker KF, Hofler H, van RF. Mutations of the human E-cadherin (CDH1) gene. Hum Mutat 1998; 12:226-237.

14. Si HX, Tsao SW, Lam KY et al. E-cadherin expression is commonly downregulated by $\mathrm{CpG}$ island hypermethylation in esophageal carcinoma cells. Cancer Lett 2001; 173:71-78.

15. Lin YC, Wu MY, Li DR, Wu XY, Zheng RM. Prognostic and clinicopathological 
features of E-cadherin, alpha-catenin, beta-catenin, gamma-catenin and cyclin D1 expression in human esophageal squamous cell carcinoma. World J Gastroenterol 2004; 10:3235-3239.

16. Zhao XJ, Li H, Chen H, Liu YX, Zhang LH, Liu SX, Feng QL. Expression of e-cadherin and beta-catenin in human esophageal squamous cell carcinoma: relationships with prognosis. World J Gastroenterol 2003; 9:225-232.

17. Uchikado Y, Natsugoe S, Okumura H, Setoyama T, Matsumoto M, Ishigami S, Aikou T. Slug Expression in the E-cadherin preserved tumors is related to prognosis in patients with esophageal squamous cell carcinoma. Clin Cancer Res 2005; 11:1174-1180.

18. Inada S, Koto T, Futami K, Arima S, Iwashita A. Evaluation of malignancy and the prognosis of esophageal cancer based on an immunohistochemical study (p53, E-cadherin, epidermal growth factor receptor). Surg Today 1999; 29:493-503.

19. Nair KS, Naidoo R, Chetty R. Microsatellite analysis of the APC gene and 
immunoexpression of E-cadherin, catenin, and tubulin in esophageal squamous cell carcinoma. Hum Pathol 2006; 37:125-134.

20. Sato F, Shimada Y, Watanabe G, Uchida S, Makino T, Imamura M. Expression of vascular endothelial growth factor, matrix metalloproteinase-9 and E-cadherin in the process of lymph node metastasis in oesophageal cancer. Br J Cancer 1999; 80:1366-1372.

21. Gamboa-Dominguez A, Dominguez-Fonseca C, Chavarri-Guerra Y et al. E-cadherin expression in sporadic gastric cancer from Mexico: exon 8 and 9 deletions are infrequent events associated with poor survival. Hum Pathol 2005; 36:29-35.

22. Keirsebilck A, Bonne S, Staes K, van HJ, Nollet F, Reynolds A, van RF. Molecular cloning of the human p120ctn catenin gene (CTNND1): expression of multiple alternatively spliced isoforms. Genomics 1998; 50:129-146.

23. Davis MA, Ireton RC, Reynolds AB. A core function for p120-catenin in cadherin turnover. J Cell Biol 2003; 163:525-534. 
24. Grosheva I, Shtutman M, Elbaum M, Bershadsky AD. p120 catenin affects cell motility via modulation of activity of Rho-family GTPases: a link between cell-cell contact formation and regulation of cell locomotion. J Cell Sci 2001; 114:695-707.

25. Franz CM, Ridley AJ. p120 catenin associates with microtubules: inverse relationship between microtubule binding and Rho GTPase regulation. J Biol Chem 2004; 279:6588-6594.

26. Noren NK, Liu BP, Burridge K, Kreft B. p120 catenin regulates the actin cytoskeleton via Rho family GTPases. J Cell Biol 2000; 150:567-580.

27. Anastasiadis PZ, Reynolds AB. Regulation of Rho GTPases by p120-catenin. Curr Opin Cell Biol 2001; 13:604-610.

28. Wijnhoven BP, Pignatelli M, Dinjens WN, Tilanus HW. Reduced p120ctn expression correlates with poor survival in patients with adenocarcinoma of the gastroesophageal junction. J Surg Oncol 2005; 92:116-123.

29. Bremnes RM, Veve R, Gabrielson E et al. High-throughput tissue microarray analysis 
used to evaluate biology and prognostic significance of the E-cadherin pathway in non-small-cell lung cancer. J Clin Oncol 2002; 20:2417-2428.

30. AJCC cancer staging manual / American Joint Committee on Cancer. New York: Springer 2002;91-95.

31. Fujimoto D, Hirono Y, Goi T, Katayama K, Hirose K, Yamaguchi A. Expression of protease activated receptor-2 (PAR-2) in gastric cancer. J Surg Oncol 2006; 93:139-144.

32. Tomita K, van BA, van Leenders GJ, Ruijter ET, Jansen CF, Bussemakers MJ, Schalken JA. Cadherin switching in human prostate cancer progression. Cancer Res $2000 ; 60: 3650-3654$.

33. Feith M, Stein HJ, Mueller J, Siewert JR. Malignant degeneration of Barrett's esophagus: the role of the Ki-67 proliferation fraction, expression of E-cadherin and p53. Dis Esophagus 2004; 17:322-327.

34. Bosch FX, Andl C, Abel U, Kartenbeck J. E-cadherin is a selective and strongly 
dominant prognostic factor in squamous cell carcinoma: a comparison of E-cadherin with desmosomal components. Int J Cancer 2005; 114:779-790.

35. Bellovin DI, Bates RC, Muzikansky A, Rimm DL, Mercurio AM. Altered localization of p120 catenin during epithelial to mesenchymal transition of colon carcinoma is prognostic for aggressive disease. Cancer Res 2005; 65:10938-10945.

36. Hazan RB, Phillips GR, Qiao RF, Norton L, Aaronson SA. Exogenous expression of $\mathrm{N}$-cadherin in breast cancer cells induces cell migration, invasion, and metastasis. J Cell Biol 2000; 148:779-790.

37. Fukudome Y, Yanagihara K, Takeichi M, Ito F, Shibamoto S. Characterization of a mutant E-cadherin protein encoded by a mutant gene frequently seen in diffuse-type human gastric carcinoma. Int J Cancer 2000; 88:579-583.

38. Ishizaki Y, Omori Y, Momiyama M, Nishikawa Y, Tokairin T, Manabe M, Enomoto K. Reduced expression and aberrant localization of p120catenin in human squamous cell carcinoma of the skin. J Dermatol Sci 2004; 34:99-108. 
39. van HJ, Vanhoenacker P, Staes K, van RF. Nuclear localization of the p120(ctn) Armadillo-like catenin is counteracted by a nuclear export signal and by E-cadherin expression. Proc Natl Acad Sci U S A 1999; 96:7980-7985.

40. Thoreson MA, Anastasiadis PZ, Daniel JM et al. Selective uncoupling of p120(ctn) from E-cadherin disrupts strong adhesion. J Cell Biol 2000; 148:189-202.

41. Ireton RC, Davis MA, van $\mathrm{HJ}$ et al. A novel role for p120 catenin in E-cadherin function. J Cell Biol 2002; 159:465-476.

42. Yanagisawa M, Kaverina IN, Wang A, Fujita Y, Reynolds AB, Anastasiadis PZ. A novel interaction between kinesin and p120 modulates p120 localization and function.

J Biol Chem 2004; 279:9512-9521.

43. Lu Q, Dobbs LJ, Gregory CW, Lanford GW, Revelo MP, Shappell S, Chen YH. Increased expression of delta-catenin/neural plakophilin-related armadillo protein is associated with the down-regulation and redistribution of E-cadherin and p120ctn in human prostate cancer. Hum Pathol 2005; 36:1037-1048. 
44. Montonen O, Aho M, Uitto J, Aho S. Tissue distribution and cell type-specific expression of p120ctn isoforms. J Histochem Cytochem 2001; 49:1487-1496.

45. Aho S, Levansuo L, Montonen O, Kari C, Rodeck U, Uitto J. Specific sequences in p120ctn determine subcellular distribution of its multiple isoforms involved in cellular adhesion of normal and malignant epithelial cells. J Cell Sci 2002;

115:1391-1402. 


\section{LEGENDS TO FIGURES}

FIGURE 1. Expression of E-cadherin and p120ctn in ESCCs. A, strong membranous expression of E-cadherin in non-tumor tissue (x200); $B$, strong membranous expression of p120ctn in non-tumor tissue (x200); C, reduced expression of E-cadherin in tumor (x200); $D$, membranous loss and cytoplasmic accumulation of p120ctn in tumor (x400); E, heterogeneous expression of E-cadherin in dysplasia (x250); F, heterogeneous expression and localization of p120ctn in dysplasia (x250).

FIGURE 2. Survival curves of ESCC patients with esophageal squamous cell carcinoma (ESCC), according to the expression of E-cadherin (A), expression of p120ctn (B) and localization of p120ctn (C). No significant difference was observed when the parameters were compared by log rank test. 


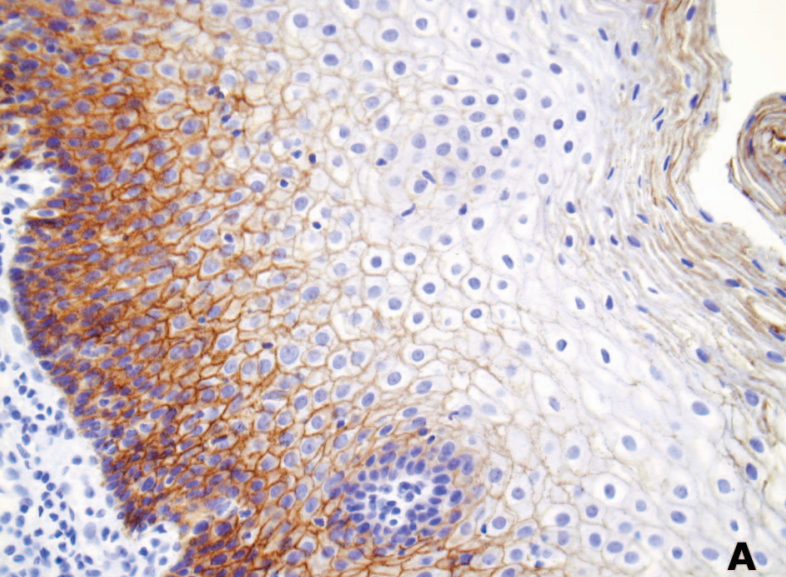




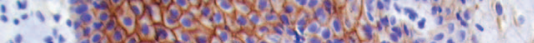

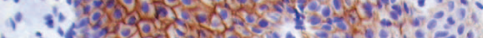

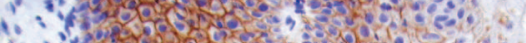

1) 4.

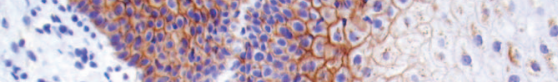

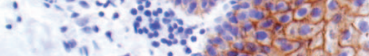

$\because$ in the

, ant

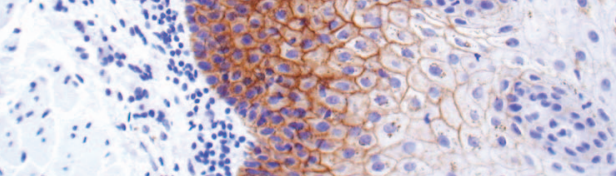

$\therefore \therefore$ - $\because 4$

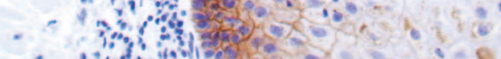

$\therefore \quad$ at

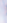

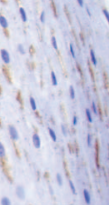

$\frac{1}{4}$

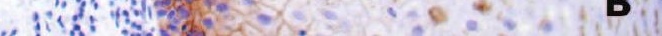




\section{a}

$1+$

2istis)

wit $y-63(08) x y$

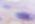

40

$(2,5)$

3.4

cis

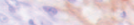

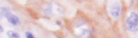

18

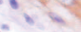

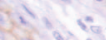

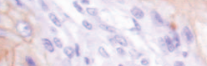

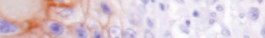

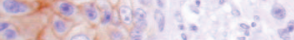

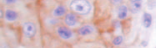

(-6)

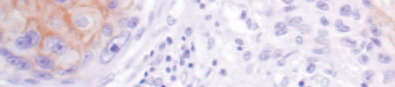

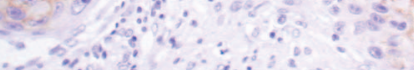

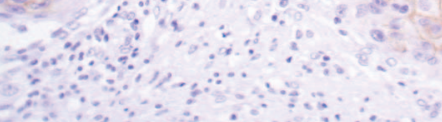

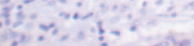<smiles></smiles>

1

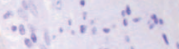




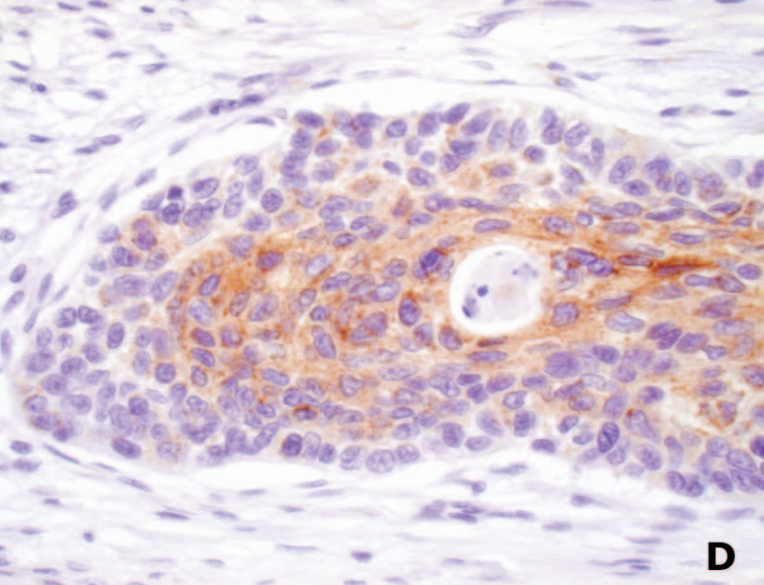




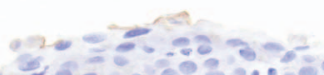

$=0$

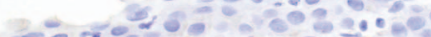

-

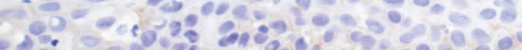

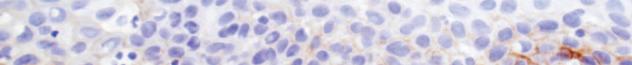

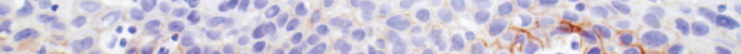

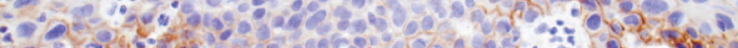

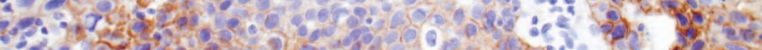

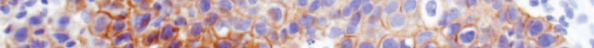

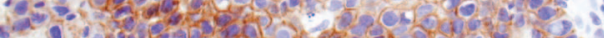

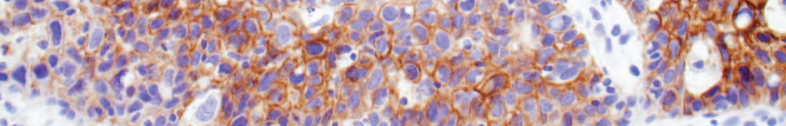
की

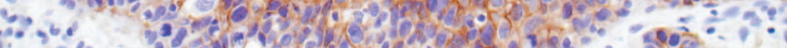

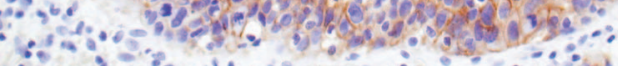

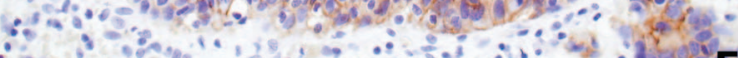

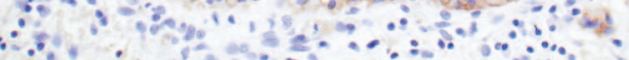




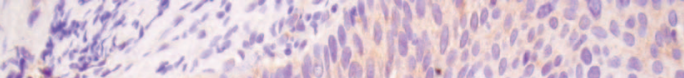

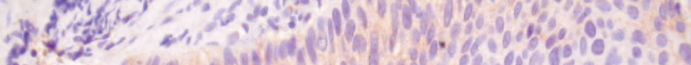

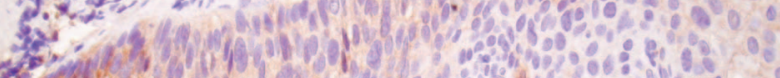

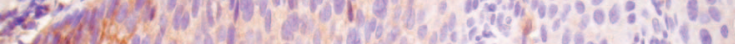

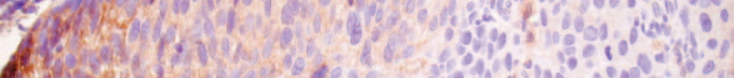

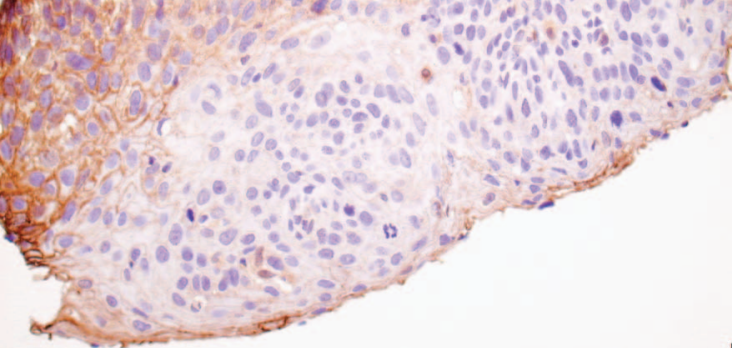




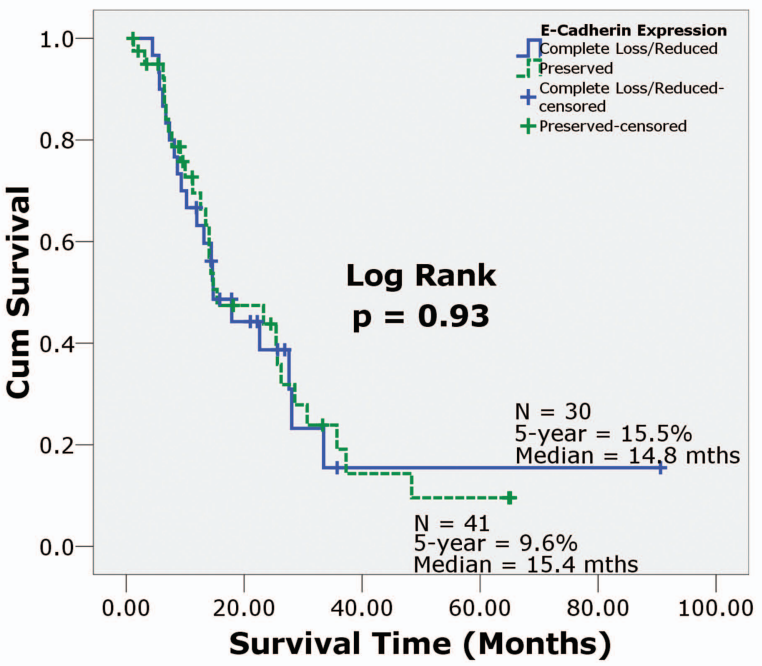




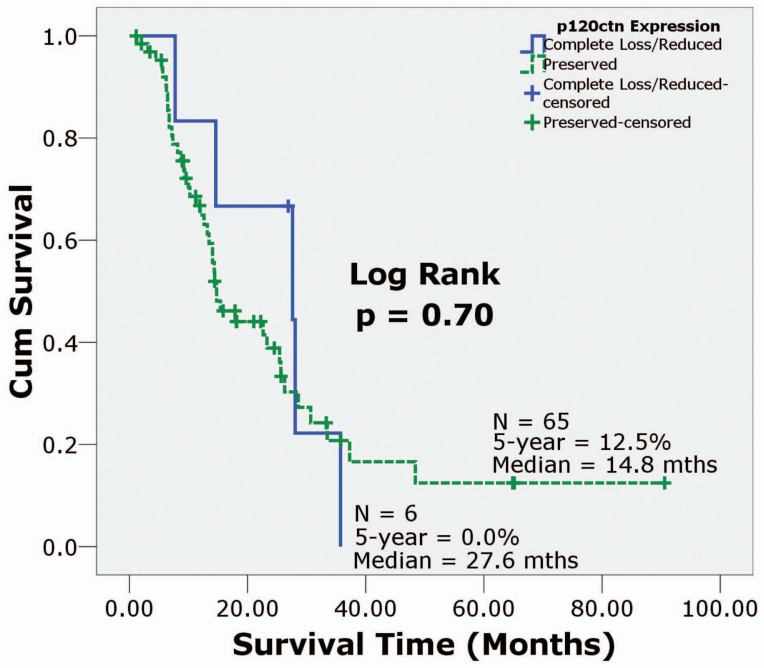




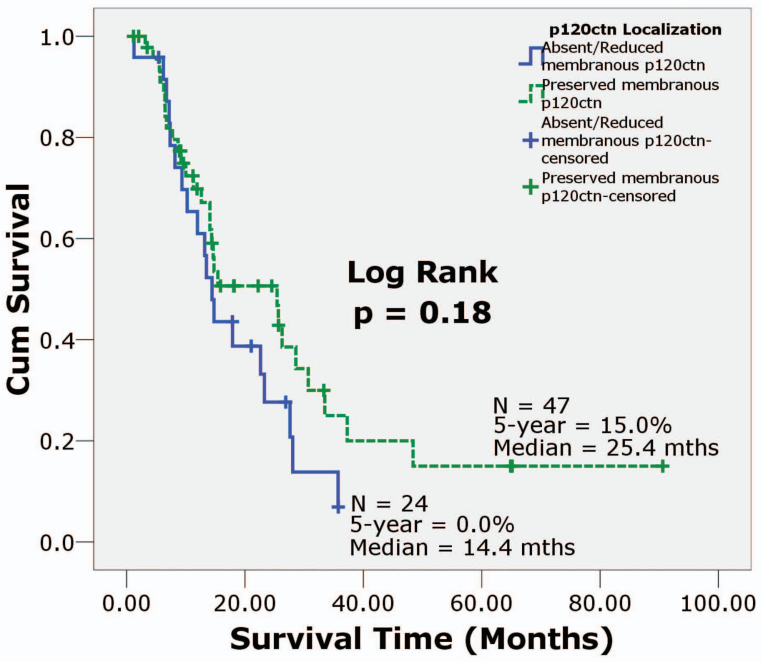


TABLE 1

Relationship of E-cadherin expression and p120ctn localization

\begin{tabular}{|c|c|c|c|c|}
\hline & \multicolumn{3}{|c|}{ p120ctn Localization } \\
\hline & & Absent / Reduced Membranous & Preserved Membranous & $P$ value \\
\hline \multirow{4}{*}{$\begin{array}{l}\text { E-cadherin } \\
\text { Expression }\end{array}$} & Complete Loss / & 17 & 13 & \multirow{4}{*}{0.001} \\
\hline & Reduced & $(23.9 \%)$ & $(18.3 \%)$ & \\
\hline & \multirow{2}{*}{ Preserved } & 7 & 34 & \\
\hline & & $(9.9 \%)$ & $(47.9 \%)$ & \\
\hline
\end{tabular}


TABLE 2

Relationship of E-cadherin expression and clinicopathological characteristics

\begin{tabular}{|c|c|c|c|c|c|}
\hline \multicolumn{2}{|c|}{$\underline{\text { Characteristics }}$} & Total & $\begin{array}{c}\text { Complete Loss / Reduced } \\
\begin{array}{c}\text { E-cadherin Expression } \\
\mathrm{n}=30 / 71(42.3 \%)\end{array}\end{array}$ & $\begin{array}{c}\text { Preserved E-cadherin } \\
\text { Expression } \\
\mathrm{n}=41 / 71(57.7 \%)\end{array}$ & $\underline{P \text { value }}$ \\
\hline \multicolumn{2}{|c|}{ Age $($ Mean \pm SD $)$} & $\mathrm{n}=71$ & $64.43 \pm 10.27$ & $65.34 \pm 12.25$ & 0.627 \\
\hline Gender & $\begin{array}{l}\text { Male } \\
\text { Female }\end{array}$ & $\begin{array}{l}50(70.4 \%) \\
21(29.6 \%)\end{array}$ & $\begin{array}{l}23(76.7 \%) \\
7(23.3 \%)\end{array}$ & $\begin{array}{l}27(65.9 \%) \\
14(34.1 \%)\end{array}$ & 0.432 \\
\hline $\begin{array}{l}\text { Smoking } \\
\text { Status }\end{array}$ & $\begin{array}{l}\text { Smoker } \\
\text { Non-smoker }\end{array}$ & $\begin{array}{l}35(49.3 \%) \\
36(50.7 \%)\end{array}$ & $\begin{array}{l}14(46.7 \%) \\
16(53.3 \%)\end{array}$ & $\begin{array}{l}21(51.2 \%) \\
20(48.8 \%)\end{array}$ & 0.811 \\
\hline $\begin{array}{l}\text { Level of } \\
\text { Tumor }\end{array}$ & $\begin{array}{l}\text { Upper } \\
\text { Middle } \\
\text { Lower } \\
\text { Double }\end{array}$ & $\begin{array}{c}10(14.1 \%) \\
41(57.7 \%) \\
17(23.9 \%) \\
3(4.2 \%)\end{array}$ & $\begin{array}{c}5(16.7 \%) \\
14(46.7 \%) \\
10(33.3 \%) \\
1(3.3 \%)\end{array}$ & $\begin{array}{c}5(12.2 \%) \\
27(65.9 \%) \\
7(17.1 \%) \\
2(4.9 \%)\end{array}$ & 0.339 \\
\hline $\begin{array}{l}\text { Tumor } \\
\text { Differentiation }\end{array}$ & $\begin{array}{l}\text { Well } \\
\text { Moderate } \\
\text { Poor }\end{array}$ & $\begin{array}{l}12(16.9 \%) \\
44(62.0 \%) \\
15(21.1 \%)\end{array}$ & $\begin{array}{c}0(0.0 \%) \\
19(63.3 \%) \\
11(36.7 \%)\end{array}$ & $\begin{array}{c}12(29.3 \%) \\
25(61.0 \%) \\
4(9.8 \%)\end{array}$ & 0.001 \\
\hline R Category & $\begin{array}{l}\mathrm{R} 0 \\
\mathrm{R} 1 / \mathrm{R} 2\end{array}$ & $\begin{array}{l}53(74.6 \%) \\
18(25.4 \%)\end{array}$ & $\begin{array}{l}26(86.7 \%) \\
4(13.3 \%)\end{array}$ & $\begin{array}{l}27(65.9 \%) \\
14(34.1 \%)\end{array}$ & 0.057 \\
\hline $\begin{array}{l}\text { Pathological } \\
\text { T-Stage }\end{array}$ & $\begin{array}{l}\text { Early (T1/T2) } \\
\text { Late (T3/T4) }\end{array}$ & $\begin{array}{l}16(22.5 \%) \\
55(77.5 \%)\end{array}$ & $\begin{array}{l}6(20.0 \%) \\
24(80.0 \%)\end{array}$ & $\begin{array}{l}10(24.4 \%) \\
31(75.6 \%)\end{array}$ & 0.777 \\
\hline $\begin{array}{l}\text { Pathological } \\
\text { N-Stage }\end{array}$ & $\begin{array}{l}\text { N0 } \\
\text { N1 }\end{array}$ & $\begin{array}{l}28(39.4 \%) \\
43(60.6 \%)\end{array}$ & $\begin{array}{l}14(46.7 \%) \\
16(53.3 \%)\end{array}$ & $\begin{array}{l}14(34.1 \%) \\
27(65.9 \%)\end{array}$ & 0.332 \\
\hline $\begin{array}{l}\text { Pathological } \\
\text { M-Stage }\end{array}$ & $\begin{array}{l}\text { M0 } \\
\text { M1a } \\
\text { M1b }\end{array}$ & $\begin{array}{c}65(91.5 \%) \\
2(2.8 \%) \\
4(5.6 \%)\end{array}$ & $\begin{array}{c}29(96.7 \%) \\
0(0.0 \%) \\
1(3.3 \%)\end{array}$ & $\begin{array}{c}36(87.8 \%) \\
2(4.9 \%) \\
3(7.3 \%)\end{array}$ & 0.350 \\
\hline $\begin{array}{l}\text { Pathological } \\
\text { Stage }\end{array}$ & $\begin{array}{l}\text { Early (I/II) } \\
\text { Advanced (III/IV) }\end{array}$ & $\begin{array}{l}30(42.3 \%) \\
41(57.7 \%)\end{array}$ & $\begin{array}{l}13(43.3 \%) \\
17(56.7 \%)\end{array}$ & $\begin{array}{l}17(41.5 \%) \\
24(58.5 \%)\end{array}$ & 1.000 \\
\hline
\end{tabular}


TABLE 3

Relationship of p120ctn localization and clinicopathological characteristics

\begin{tabular}{|c|c|c|c|c|c|}
\hline \multicolumn{2}{|c|}{ Characteristics } & $\underline{\text { Total }}$ & $\begin{array}{c}\text { Absent / Reduced } \\
\text { Membranous p120ctn } \\
n=24 / 71(33.8 \%)\end{array}$ & $\begin{array}{c}\text { Preserved Membranous } \\
\text { p120ctn } \\
\mathrm{n}=47 / 71(66.2 \%)\end{array}$ & $\underline{P \text { value }}$ \\
\hline \multicolumn{2}{|c|}{ Age $($ Mean \pm SD) } & $\mathrm{n}=71$ & $65.71 \pm 11.54$ & $64.57 \pm 11.41$ & 0.405 \\
\hline Gender & $\begin{array}{l}\text { Male } \\
\text { Female }\end{array}$ & $\begin{array}{l}50(70.4 \%) \\
21(29.6 \%)\end{array}$ & $\begin{array}{l}15(62.5 \%) \\
9(37.5 \%)\end{array}$ & $\begin{array}{l}35(74.5 \%) \\
12(25.5 \%)\end{array}$ & 0.410 \\
\hline $\begin{array}{l}\text { Smoking } \\
\text { Status }\end{array}$ & $\begin{array}{l}\text { Smoker } \\
\text { Non-smoker }\end{array}$ & $\begin{array}{l}35(49.3 \%) \\
36(50.7 \%)\end{array}$ & $\begin{array}{l}8(33.3 \%) \\
16(66.7 \%)\end{array}$ & $\begin{array}{l}27(57.4 \%) \\
20(42.6 \%)\end{array}$ & 0.079 \\
\hline $\begin{array}{l}\text { Level of } \\
\text { Tumor }\end{array}$ & $\begin{array}{l}\text { Upper } \\
\text { Middle } \\
\text { Lower } \\
\text { Double }\end{array}$ & $\begin{array}{c}10(14.1 \%) \\
41(57.7 \%) \\
17(23.9 \%) \\
3(4.2 \%)\end{array}$ & $\begin{array}{c}5(20.8 \%) \\
14(58.3 \%) \\
3(12.5 \%) \\
2(8.3 \%)\end{array}$ & $\begin{array}{c}5(10.6 \%) \\
27(57.4 \%) \\
14(29.8 \%) \\
1(2.1 \%)\end{array}$ & 0.203 \\
\hline $\begin{array}{l}\text { Tumor } \\
\text { Differentiation }\end{array}$ & $\begin{array}{l}\text { Well } \\
\text { Moderate } \\
\text { Poor }\end{array}$ & $\begin{array}{l}12(16.9 \%) \\
44(62.0 \%) \\
15(21.1 \%)\end{array}$ & $\begin{array}{c}2(8.3 \%) \\
12(50.0 \%) \\
10(41.7 \%)\end{array}$ & $\begin{array}{c}10(21.3 \%) \\
32(68.1 \%) \\
5(10.6 \%)\end{array}$ & 0.008 \\
\hline R Category & $\begin{array}{l}\text { R0 } \\
\text { R1/R2 }\end{array}$ & $\begin{array}{l}53(74.6 \%) \\
18(25.4 \%)\end{array}$ & $\begin{array}{l}18(75.0 \%) \\
6(25.0 \%)\end{array}$ & $\begin{array}{l}35(74.5 \%) \\
12(25.5 \%)\end{array}$ & 1.000 \\
\hline $\begin{array}{l}\text { Pathological } \\
\text { T-Stage }\end{array}$ & $\begin{array}{l}\text { Early (T1/T2) } \\
\text { Late (T3/T4) }\end{array}$ & $\begin{array}{l}16(22.5 \%) \\
55(77.5 \%)\end{array}$ & $\begin{array}{l}6(25.0 \%) \\
18(75.0 \%)\end{array}$ & $\begin{array}{l}10(21.3 \%) \\
37(78.7 \%)\end{array}$ & 0.769 \\
\hline $\begin{array}{l}\text { Pathological } \\
\text { N-Stage }\end{array}$ & $\begin{array}{l}\text { N0 } \\
\text { N1 }\end{array}$ & $\begin{array}{l}28(39.4 \%) \\
43(60.6 \%)\end{array}$ & $\begin{array}{l}11(45.8 \%) \\
13(54.2 \%)\end{array}$ & $\begin{array}{l}17(36.2 \%) \\
30(63.8 \%)\end{array}$ & 0.453 \\
\hline $\begin{array}{l}\text { Pathological } \\
\text { M-Stage }\end{array}$ & $\begin{array}{l}\text { M0 } \\
\text { M1a } \\
\text { M1b }\end{array}$ & $\begin{array}{c}65(91.5 \%) \\
2(2.8 \%) \\
4(5.6 \%)\end{array}$ & $\begin{array}{c}24(100.0 \%) \\
0(0.0 \%) \\
0(0.0 \%)\end{array}$ & $\begin{array}{c}41(87.2 \%) \\
2(4.3 \%) \\
4(8.5 \%)\end{array}$ & 0.188 \\
\hline $\begin{array}{l}\text { Pathological } \\
\text { Stage }\end{array}$ & $\begin{array}{l}\text { Early (I/II) } \\
\text { Advanced (III/IV) }\end{array}$ & $\begin{array}{l}30(42.3 \%) \\
41(57.7 \%)\end{array}$ & $\begin{array}{l}11(45.8 \%) \\
13(54.2 \%)\end{array}$ & $\begin{array}{l}19(40.4 \%) \\
28(59.6 \%)\end{array}$ & 0.800 \\
\hline
\end{tabular}

